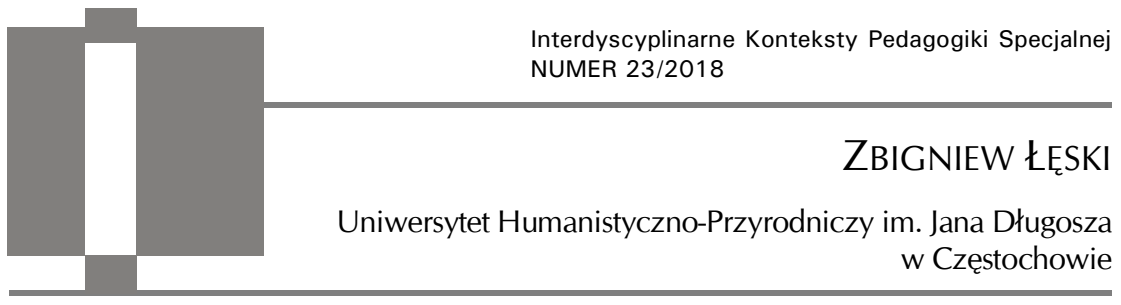

\title{
Edukacja medialna z perspektywy edukacyjnej analizy transakcyjnej
}

\begin{abstract}
Zbigniew Łęski, Edukacja medialna z perspektywy edukacyjnej analizy transakcyjnej [Media education from the perspective of educational transactional analysis]. Interdyscyplinarne Konteksty Pedagogiki Specjalnej, nr 23, Poznań 2018. Pp. 111-123. Adam Mickiewicz University Press. ISSN 2300-391X. DOI: https:/ doi. org/10.14746/ikps.2018.23.06

Educational transactional analysis is one of the main branches of transactional analysis - a concept which was created for psychotherapy. Its tools and clear terminology allow for both theoretical and empirical analysis of many aspects connected with the specificity of human functioning in the world of new media. The article shows possibilities of its application and offers a review of the existing theoretical and empirical initiatives that deal with this issue.
\end{abstract}

KEY WORDS: transactional analysis, new media, human-computer relationship, media education

Koncepcja analizy transakcyjnej (w skrócie AT) zdobywa coraz to większą popularność wśród osób zajmujących się problematyką związaną z edukacją. Teoria ta daje badaczowi do dyspozycji przejrzyste pojęcia oraz gotowe do wykorzystania narzędzia. Dzięki jej zastosowaniu możemy przyjrzeć się m.in. specyfice relacji pomiędzy poszczególnymi podmiotami analizowanej rzeczywistości, ich postawom życiowym, zaobserwować i zidentyfikować gry interper- 
sonalne i wiele innych, istotnych elementów. Nic zatem dziwnego, że edukacyjna analiza transakcyjna to obecnie jedna $\mathrm{z}$ głównych gałęzi AT, która bardzo dynamicznie się rozwija. W Częstochowie, na Uniwersytecie Huminiastyczno-Przyrodniczym im. J. Długosza, działa Zespół Badawczy Edukacyjnej Analizy Transakcyjnej¹, którego członkiem jest m.in. autor niniejszego artykułu. Inspiracją do jego powstania stała się potrzeba uporządkowania i usystematyzowania tego, co w zakresie wykorzystania AT w analizie problematyki związanej $\mathrm{z}$ edukacją medialną udało się osiągnąć $\mathrm{w}$ ciągu ostatnich kilku lat. Jedną z pierwszych prób połączenia przysłowiowego ognia $z$ wodą, czyli teorii powstałej na potrzeby psychoterapii, jaką jest analiza transakcyjna, z tematyką funkcjonowania człowieka w świecie nowych mediów był artykuł autora opublikowany w roku 2011. W rozważaniach tam zawartych wskazano na możliwe obszary wykorzystania terminologii oraz narzędzi jakie dostarcza AT w analizie problematyki komputeryzacji procesu kształcenia2 ${ }^{2}$ Był to wówczas jeszcze przede wszystkim zbiór pomysłów, z których jakaś część w ciągu kolejnych lat została zweryfikowana lub wykorzystana. Warto zatem teraz spojrzeć na nie z perspektywy zebranych doświadczeń i tym samym ocenić, które z nich udało się zrealizować, które się nie sprawdziły i wymagają korekt i przemyśleń, a które nadal czekają na realizację.

Aby jednak dobrze zrozumieć rozważania zawarte w dalszej części artykułu, warto najpierw przywołać najważniejsze założenia analizy transakcyjnej. Przy czym będzie to jedynie bardzo ogólny zarys. Po pierwsze trudno zaprezentować szczegóły rozbudowanej koncepcji, która rozwija się od połowy XX w. w jednym, ograniczonym objętościowo artykule, a po drugie istnieje cały szereg wartościowych publikacji w tym zakresie, do których warto odesłać tych czytelników, którzy szerzej zainteresują się poruszaną tu tematyką

${ }^{1}$ Więcej na stronie Zespołu: http:/ / eat.ujd.edu.pl [dostęp: 15.08.2018].

2 Z. Łęski, Zarys problematyki komputeryzacji ksztatcenia w perspektywie analizy transakcyjnej, [w:] Analiza transakcyjna w edukacji, red. J. Jagieła, Wydawnictwo im. S. Podobińskiego Akademii im. J. Długosza w Częstochowie, Częstochowa 2011, s. 140-153. 
i zechcą wykorzystywać AT w swojej pracy naukowej. Mowa tu np. o pozycjach autorstwa twórcy analizy transakcyjnej Erica Berne ${ }^{3}$, o podręczniku Analiza transakcyjna dzisiaj Iana Stewarta oraz Vanna Joinesa4, pracy zbiorowej Analiza transakcyjna w edukacji pod redakcją Jarosława Jagieły ${ }^{5}$ czy też, wydawanym przez wspomniany powyżej Zespół Badawczy, roczniku „Edukacyjna Analiza Transakcyjna" 6 .

Za podstawę analizy transakcyjnej uważa się analizę strukturalną. Bez jej znajomości nie da się zrozumieć większości założeń tej koncepcji oraz zastosować jej czy to w praktyce edukacyjnej, czy w działalności naukowo-badawczej. Zgodnie z jej założeniami każdy z nas posiada trzy podstawowe stany Ja: Rodzica, Dorosłego oraz Dziecko. W uproszczeniu - pierwszy z nich odpowiada za te myśli, uczucia i działania, których źródłem są przekazy rodzicielskie. Działając z tej pozycji, kierujemy się zwykle gotowymi i sprawdzonymi wzorami, normami i zasadami. Również tu będą umiejscowione uczucia związane chociażby z troską i opiekuńczością. Dziecko z kolei jest stanem odzwierciedlającym naturalność, spontaniczność, radość, kreatywność, ale jednocześnie - strach czy egoizm. Natomiast Dorosły odpowiada za działania, myśli i uczucia osoby dorosłej - rozsądnej, myślącej logicznie, analizującej, podejmującej konstruktywne decyzje itp $\mathrm{p}^{7}$. W każdym momencie występujemy $\mathrm{z}$ poziomu jednego $\mathrm{z}$ naszych stanów Ja, a przełączanie pomiędzy nimi określa się terminem kateksji (cathesis). Niemożliwe

${ }^{3}$ Zob.: E. Berne, W co graja ludzie, Wydawnictwo Naukowe PWN, Warszawa 1994.

${ }^{4}$ Zob.: I. Stevart, V. Joines. Analiza transakcyjna dzisiaj, Dom Wydawniczy REBIS, Poznań 2017.

${ }^{5}$ Analiza transakcyjna w edukacji, red. J. Jagieła, Wydawnictwo im. S. Podobińskiego Akademii im. J. Długosza w Częstochowie, Częstochowa 2011.

${ }^{6}$ Czasopismo dostępne na stronie internetowej: https://czasopisma.ujd.edu. pl/index.php/EAT [dostęp: 15.08.2018].

7 E. Berne, Seks i kochanie, Wydawnictwo Książka i Wiedza, Warszawa 1994, s. 81-82; I. Stewart, V. Joines, Analiza transakcyjna dzisiaj, Dom Wydawniczy REBIS, Poznań 2017, s. 13-19. 
przy tym jest kateksjonowanie dwóch stanów jednocześnie ${ }^{8}$. Oczywiście powyższy opis to jedynie zarys tego, czym jest analiza strukturalna i może budzić wątpliwości, czy nie jest on zbyt uproszczony, aby móc rzetelnie odzwierciedlać funkcjonowanie człowieka $\mathrm{w}$ danej chwili. Dlatego też w analizie transakcyjnej dokonujemy dalszych podziałów. Mamy do dyspozycji analizę funkcjonalną, w której w obrębie Rodzica wyróżniamy Rodzica Normatywnego oraz Opiekuńczego, a w obrębie Dziecka - Wolne i Przystosowane9. Z kolei w analizie strukturalnej drugiego stopnia wyróżniamy dodatkowe stany Rodzica, Dorosłego i Dziecka w obrębie głównych stanów Ja Rodzic oraz Ja Dziecko. I tak uzyskujemy np. Dorosłego w Rodzicu czy Dziecko w Rodzicu itd ${ }^{10}$. Rozpoznanie profilu korzystania ze swoich stanów Ja przez jednostkę dostarcza nam bardzo wielu istotnych informacji o źródłach jej myśli, uczuć i zachowań, a przypadku pojawienia się sytuacji problemowej, pozwala na podjęcie skutecznych działań diagnostycznych oraz profilaktycznych. Dodatkowo mamy tu do dyspozycji egogramy, czyli kwestionariusze badające funkcjonowanie człowieka w stanach Ja. Dostępne są zarówno takie, które ukierunkowane są na analizę funkcjonalną, jak i takie, które biorą pod uwagę analizę strukturalną drugiego stopnia.

Kolejne ważne pojęcie zawarte jest w samej nazwie koncepcji analizy transakcyjnej. Mowa tu mianowicie o transakcjach. Terminem tym E. Berne określił jednostkę stosunków międzyludzkich. Nawiązując relację z drugim człowiekiem (np. poprzez komunikat werbalny, lub niewerbalny), wysyłamy bodziec transakcyjny. Odpowiedź na bodziec określa się mianem reakcji transakcyjnej ${ }^{11}$. Bodźce i reakcje transakcyjne przebiegają pomiędzy stanami Ja.

8 A. Pierzchała, Pasywność w szkole. Diagnoza zjawiska z perspektywy analizy transakcyjnej, Wydawnictwo im. S. Podobińskiego Akademii im. J. Długosza w Częstochowie, Częstochowa 2013, s. 36.

${ }^{9}$ I. Stewart, V. Joines, op. cit., s. 27-40.

10 Ibidem, s. 41-55.

${ }^{11}$ E. Berne, W co grają ludzie, Wydawnictwo Naukowe PWN, Warszawa 1994, s. 21. 
Będąc w pozycji Dorosłego, z tego właśnie poziomu wyślemy komunikat i skierujemy go zapewne do stanu Ja Dorosły drugiego człowieka, oczekując tym samym rzeczowej i logicznej odpowiedzi. Jeśli ją uzyskamy, będziemy mieli do czynienia z transakcją równoległą (komplementarną), która sprzyja efektywnemu komunikowaniu się i w znacznym stopniu minimalizuje ryzyko pojawienia się sytuacji konfliktowej. Innym przykładem takiej właśnie transakcji jest np. zabawa (Dziecko - Dziecko) albo ktoś posłusznie wykonujący polecenia innej osoby (Rodzic - Dziecko). Jeśli jednak reakcja wyjdzie z innego stanu Ja niż ten, do którego została skierowana (i/lub trafi do innego), wtedy mówimy o transakcjach skrzyżowanych. Reakcja transakcyjna może być wtedy niespójna w stosunku do bodźca i niezgodna z oczekiwaniami, co w konsekwencji generować może sytuacje konfliktowe ${ }^{12}$.

Analiza transakcyjna zajmuje się również wpływem, jaki mogą mieć przekazy ważnych dla nas osób oraz zbierane w ciągu życia doświadczenia, na nasze codzienne funkcjonowanie oraz podejmowane decyzje. Mówi się w takim wypadku o analizie skryptu życiowego, czyli inaczej - ukrytego scenariusza życia. Jest to swoisty program życiowy, który zaczyna się kształtować od momentu narodzin, a w dorosłym życiu jest realizowany w kontekście społecznym. Człowiek odgrywa role bohaterów, prześladowców, ofiar, poszukując zarazem partnerów do komplementarnych i drugorzędnych ról. Skryptem objęte są przy tym nie tylko jednostki, ale też grupy społeczne, rodziny czy nawet całe narody ${ }^{13}$. Z perspektywy edukacyjnej analizy transakcyjnej bardzo ciekawym zagadnieniem jest skrypt szkoły jako instytucji. Jego analiza może pomóc w zrozumieniu przyczyn oporu przed zmianą form oraz metod pracy dydaktycznej stosowanych przez nauczycieli ${ }^{14}$. Sama analiza

12 Ibidem, s. 21-25.

${ }^{13}$ M. James, D. Jongeward, Narodzić się, by wygrać, Dom wydawniczy REBIS, Poznań, 2003, s. 103-105.

14 A. Pierzchała, Transakcyjne zakazy i nakazy skryptowe w ukrytym programie szkoty, „Edukacyjna Analiza Transakcyjna” 2017, nr 6, s. 107-117. 
skryptu jest zadaniem niezwykle trudnym i zwykle dokonywana jest $\mathrm{w}$ trakcie procesu psychoterapeutycznego. Mówiąc o skrypcie, mamy jednak do czynienia również z nakazami skryptowymi, które $\mathrm{w}$ znacznym stopniu determinują podejmowane przez jednostkę (lub grupę czy instytucję) działania. Należą do nich:

1. Bądź doskonały.

2. Bądź silny.

3. Staraj się.

4. Sprawiaj przyjemność (innym).

5. Spiesz się ${ }^{15}$.

Każdy z powyżej wymienionych nakazów przejawia się w postaci sekwencji działań, które można obserwować i poddawać analizie, a które zarazem mogą również determinować pewne obszary oraz sposoby naszego funkcjonowania również w cyberprzestrzeni.

Bezpośrednio $\mathrm{z}$ koncepcją skryptu $\mathrm{w}$ analizie transakcyjnej wiąże się pojęcie pozycji życiowych. Odnosi się ono do tego, jaki jest nasz stosunek do siebie i otoczenia. Mamy tu do czynienia z możliwością przyjęcia jednej z czterech spośród następujących pozycji oraz odpowiadających im interakcji społecznych:

1. Ja jestem OK, Ty jesteś OK - współdziałanie (pozycja zdrowa).

2. Ja nie jestem OK, Ty jesteś OK - unikanie (pozycja depresyjna).

3. Ja jestem OK, Ty nie jesteś OK - odrzucanie (pozycja paranoidalna).

4. Ja nie jestem OK, Ty nie jesteś OK - bezradność (impas).

Skrypt dorosłego człowieka oparty jest na jednej z powyższych pozycji, ale jednostka nie pozostaje $\mathrm{w}$ niej przez cały czas. $\mathrm{W}$ zależności od sytuacji, relacji z otoczeniem, mogą się one zmieniać16.

Ostatnim, wartym wspomnienia w perspektywie wykorzystania analizy transakcyjnej na gruncie edukacji medialnej terminem są gry transakcyjne. $W$ uproszczeniu można powiedzieć, że jest to seria ukrytych transakcji, które zakończyć się mają uzyskaniem przez jedną ze stron korzyści psychologicznej. Każda jest pewnym proce-

15 I. Stewart, V. Joines, op. cit., s. 198.

16 Ibidem, s. 154-155. 
sem posiadającym początek, kulminację i zakończenie oraz zawiera pewną "pułapkę", w którą złapana zostaje druga strona procesu komunikacji. J. Jagieła zwraca uwagę, iż są one zwykle rodzajem mechanizmu obronnego ludzi, którzy poszukują wsparcia i uznania własnej wartości, ale zarazem nie wierzą, iż mogą to otrzymać w szczery i otwarty sposób ${ }^{17}$.

Jak opisane powyżej zagadnienia można odnieść do problematyki edukacji medialnej? $\mathrm{W}$ tym miejscu warto przywołać badania przeprowadzone pod koniec XX w. przez Byrona Reevesa oraz Clifforda Nassa. W szeregu eksperymentów wykazali oni, że człowiek $\mathrm{w}$ kontakcie $\mathrm{z}$ mediami (a przede wszystkim z komputerem) ma tendencję do zachowania się $\mathrm{W}$ sposób bardzo zbliżony do tego, jak zachowuje się $\mathrm{w}$ typowych relacjach międzyludzkich. W książce, w której opublikowali wyniki swoich badań, wraz z wnioskami, jakie z nich płyną, napisali wręcz o przypisywaniu zdobyczom technologii cech, które zwykliśmy traktować jako typowo ludzkie. Warto w tym miejscu zacytować bezpośrednio słowa autorów:

Ludzkie reakcje pokazują, że media są czymś więcej niż tylko narzędziami. Media traktowane grzecznie, mogą wtargnąć $\mathrm{w}$ naszą przestrzeń osobistą, mogą posiadać osobowość, która pasuje do naszej, mogą być członkami zespołu i uaktywniać stereotypy związane z płcią. Media mogą wywoływać reakcje emocjonalne, wymagać koncentracji uwagi, zagrażać nam, wpływać na pamięć i zmieniać pojęcia tego co naturalne. Media są pełnymi uczestnikami naszego świata społecznego i rzeczywistego ${ }^{18}$.

Taki punkt widzenia $\mathrm{w}$ pierwszym momencie wydaje się być mocno dyskusyjny i kontrowersyjny. Jeśli jednak przyjrzymy się praktyce naszego codziennego obcowania ze zdobyczami nowych technologii, trudno nie przyznać autorom racji. Ile razy zdarzało

${ }^{17}$ J. Jagieła, Gry psychologiczne w szkole, Oficyna Wydawnicza Nauczycieli, Kielce 2004, s. 121.

${ }^{18}$ B. Reeves, C. Nass. Media i ludzie, Państwowy Instytut Wydawniczy, Warszawa 2000, s. 294. 
nam się złościć na komputer, poganiać go albo być mu wdzięcznym za dobrze wykonane zadanie? Czy podobne emocje wyrażamy wobec innych, używanych przez nas narzędzi? B. Reeves i C. Nass piszą o „osobowości mediów”. Oczywiście urządzenia same z siebie takowej nie posiadają. Czy jednak nie może być tak, że użytkownik faktycznie przypisuje im jakieś cechy osobowości w chwili, gdy $\mathrm{z}$ nich korzysta, niejako projektując na nie swoje $\mathrm{w}$ tym zakresie oczekiwania albo obawy? Czemu wśród osób wykształconych znajdziemy takie, które nie wyobrażają sobie życia bez technologii oraz takie, którzy podchodzą do niej lękowo? Wydawałoby się, że być może głównym czynnikiem determinującym takie postawy może być wiek, ale czy rzeczywiście? W świetle konieczności odpowiedzi na tak zadane pytania, opisane wcześniej pojęcia analizy transakcyjnej mogą się okazać (i okazują się) niezwykle przydatne.

Na początku niniejszego opracowania wspomniano o artykule, który był niejako inspiracją do napisania tego tekstu. Autor przyglądał się w nim możliwościom wykorzystania przytoczonych również $w$ niniejszym opracowaniu pojęć analizy transakcyjnej $\mathrm{w}$ badaniach związanych $\mathrm{z}$ edukacją medialną, a konkretnie $\mathrm{z}$ analizą relacyjnego charakteru kontaktu człowiek - nowe media. Skoro bowiem według badań B. Reevesa i C. Nassa przypisujemy komputerom jakąś osobowość, to może przypisujemy im także jakąś strukturę stanów Ja? A jak już wspomniano, do ich badania mamy w AT dostępne narzędzia zwane egogramami. Może też to, jak traktujemy nowe media, zależy w jakimś stopniu od naszych dominujących nakazów skryptowych czy też pozycji życiowych. W końcu może obecność komputera w naszym otoczeniu determinuje pojawienie się nowych, specyficznych gier transakcyjnych. W ciągu tych kilku lat, które minęły od publikacji tamtego artykułu, pojawiły się opracowania teoretyczne oraz kilka inicjatyw badawczych, które w niewielkim stopniu pozwalają na odpowiedź na część z powyższych wątpliwości. W 2016 r. ukazała się drukiem monografia autora niniejszego artykułu pt. Duch w maszynie... Kim jest dla nas komputer? Charakterystyka relacji $w$ języku analizy transakcyjnej. Zawiera ona m.in. wnioski z badań, w których podjęto próbę analizy przypisy- 
wanej komputerowi przez użytkownika struktury stanów Ja. Wykorzystano $\mathrm{w}$ tym celu odpowiednio dopasowany egogram przymiotnikowy autorstwa J. Jagieły ${ }^{19}$. Próba badawcza objęła 196 osób. Wyciągnięte wnioski były w pewnym stopniu zaskakujące. Spodziewano się zależności pomiędzy celem i sposobem korzystania z komputerów a przypisywanymi urządzeniom stanami Ja. Przewidywano również, że zdobycze technologii nie otrzymają od badanych pełnej struktury. Zakładano, że osoby, które te urządzenia wykorzystują głównie do pracy, przypiszą im przede wszystkim Dorosłego, a ci, którzy się głównie bawią - Dziecko. Tymczasem okazało się, że respondenci, niezależnie od czasu, celu czy sposobu korzystania z urządzeń, przypisali im strukturę, która w znacznej mierze odpowiada tej, jaką sami posiadają. Można wręcz stwierdzić, iż pojawiła się wyraźna tendencja do „uczłowieczania” ma$\operatorname{szyn}^{20}$. Stanowi to przy tym potwierdzenie wspomnianych wcześniej wniosków, jakie wyciągnęli ze swoich eksperymentów B. Reeves i C. Nass.

Wspomniana $\mathrm{w}$ powyższym akapicie publikacja to przykład wykorzystania analizy strukturalnej. Wyciągnięte wnioski mówią nam o zjawisku projektowania na maszynę podobnej struktury stanów Ja, jaką sami się posługujemy, ale o relacji człowiek - nowe technologie mówi już niewiele. $\mathrm{W}$ tym celu konieczne byłoby dokonanie analizy transakcji, co jest już niewątpliwie znacznie trudniejszym zadaniem. W pewnym zakresie podjęła się go Aanna Pierzchała w artykułach: Rodzic, Dorosty, Dziecko - jak można opisać komunikacje, na forach internetowych z punktu widzenia Analizy Transakcyjnej21 oraz Po dwóch stronach ekranu, czyli wirtualne relacje interper-

19 Z. Łęski, Duch w maszynie... Kim jest dla nas komputer? Charakterystyka relacji w języku analizy transakcyjnej, Wydawnictwo im. Stanisława Podobińskiego Akademii im. J. Długosza w Częstochowie, Częstochowa 2016, s. 115-123.

20 Ibidem, s. 63-65, 111.

21 A. Pierzchała, Rodzic, Dorosty, Dziecko - jak można opisać komunikacje na forach internetowych z punktu widzenia Analizy Transakcyjnej, [w:] Oblicza internetu. (Re)definowanie sieci, red. M. Sokołowski, Wydawnictwo Państwowej Wyzszej Szkoły Zawodowej w Elblagu, Elbląg 2010, s. 104-119. 
sonalne w perspektywie analizy transakcyjnej22. Autorka podjęła próbę jakościowej analizy wpisów na internetowych forach dyskusyjnych pod kątem identyfikacji obszarów Ja, z którego uczestnik rozpoczynał interakcję, oraz charakterystyki rodzaju wysyłanego komunikatu (zanalizowano łącznie 506 wpisów). Dominującym stanem okazał się Dorosły, poza forum poświęconym polityce, gdzie przodował Rodzic oraz forum dla samotnych, gdzie transakcje najczęściej rozpoczynano z poziomu Dziecka23. Powyższe opracowania skupiają się jednak na transakcjach zachodzących pomiędzy użytkownikami za pośrednictwem nowych technologii. Oczywiście komunikowanie się $\mathrm{w}$ cyberprzestrzeni ma swoją specyfikę i znacząco różni się od tego, z jakim mamy do czynienia w świecie rzeczywistym. Znacznie łatwiej tu wyrażać emocje, wpadać w gniew czy wbudować wypowiedzi, których w „realu” byśmy nie sformułowali. Zwracała na to uwagę Paticia Wallace w swojej Psychologii Internetu już na początku XXI w. ${ }^{24}$. Niemniej jednak wciąż pozostaje otwartym pytanie o specyfikę transakcji pomiędzy użytkownikiem a komputerem. Wciąż czekamy tu na interesujące inicjatywy badawcze i będące ich wynikiem publikacje.

Kolejne przedstawione $\mathrm{w}$ niniejszej publikacji pojęcie analizy transakcyjnej to skrypt oraz pozycje życiowe. Do tej pory drukiem ukazał się jedynie artykuł analizujący wpływ skryptu na korzystanie z komputerów od strony teoretycznej25. Obecnie jest jednak już $\mathrm{w}$ procesie wydawniczym monografia autora niniejszej publikacji,

22 A. Pierzchała, Po dwóch stronach ekranu, czyli wirtualne relacje interpersonalne w perspektywie analizy transakcyjnej, [w:] Bezpieczeństwo dzieci i młodzieży w przestrzeni wirtualnej - teoria i praktyka. Prace naukowe GWSP, red Ewa Golbik-Madej, Gliwicka Wyższa Szkoła Przedsiębiorczości, Gliwice 2016, s. 117-128.

23 Ibidem, s. 124.

24 P. Wallace, Psychologia Internetu, Dom Wydawniczy REBIS, Poznań 2005, s. 147-206.

25 Z. Łęski, A. Pierzchała, Życie w grze czy gra w życie. Rola skryptu życiowego w kształtowaniu postaw graczy, [w:] Edukacja międzykulturowa w warunkach kultury globalnej. Od rozważań definicyjnych do praktycznych zastosowań, red. N. Dębowska, M. Walachowska, N. Starik, Wydawnictwo Wyższej Szkoły Bezpieczeństwa, Poznań 2014, s. 55-63. 
która dotyka m.in. tej właśnie problematyki. W świetle przeprowadzonych na jej potrzeby badań (objęto nimi 394 osoby w wieku od 14 do 29 lat) nie zaobserwowano żadnych istotnych zależności pomiędzy takimi zmiennymi, jak: stosunek emocjonalny do nowych mediów, samoocena własnych umiejętności korzystania z nich czy cel oraz częstotliwość, z jaką badani po nie sięgają, a dominującymi dla użytkownika nakazami skryptowymi czy też jego pozycją życiową. Należy jednak podkreślić, iż respondentami byli przedstawiciele młodego pokolenia, dla których komputer i internet to jednocześnie codzienność i konieczność. Stąd też temat ten nadal pozostaje otwarty do dalszych eksploracji badawczych w innych grupach wiekowych. Warto przy tym wspomnieć, iż wspomniane badania przyniosły bardzo interesujący wniosek odnośnie do klasyfikacji tak zwanych Generacji Y oraz Generacji Z. Uzyskane wyniki podają powyższy podział w wątpliwość. Przedstawiciele Generacji Y (starsi - urodzeni między rokiem 1985 a 1999) nie różnią się od przedstawicieli Generacji Z (młodsi - urodzeni w roku 2000 i później) ani w zakresie struktury stanów Ja, ani nakazów skryptowych, ani pozycji życiowych. Nie zaobserwowano też żadnych istotnych różnic w sposobie, celu i częstotliwości korzystania z nowych technologii. Należy przy tym podkreślić, iż brakowało do tej pory rzetelnych opracowań badawczych na ten temat, a opinie wspomnianych powyżej pokoleń i różnic pomiędzy nimi kształtowane były przede wszystkim na podstawie domniemań i tez publikowanych $\mathrm{w}$ popularnych portalach internetowych.

Niezwykle ciekawym zagadnieniem wydaje się być koncepcja gier transakcyjnych w kontekście edukacji medialnej. Pojawienie się nowych mediów mogło zainicjować pojawienie się nowych gier pomiędzy użytkownikami, np. klasyczna gra - moje lepsze niż twoje - może teraz dotyczyć posiadanego smartfona i wydaje się, że jest często obserwowana pomiędzy użytkownikami różnych marek i producentów. Powstaje też pytanie, czy komunikując się w świecie cyberprzestrzeni, nie mamy większej tendencji do inicjowania gier $\mathrm{z}$ innymi ludźmi niż w świecie rzeczywistym. Warto też zwrócić uwagę, że pojawiły się też prawdopodobnie gry nawiązywane bez- 
pośrednio pomiędzy człowiekiem a medium. Nietrudno wyobrazić sobie użytkownika, który celowo manipuluje poziomem trudności gry komputerowej lub oprogramowania edukacyjnego $w$ celu udowodnienia sobie, że jest w czymś dobry albo wręcz przeciwnie - że się do czegoś nie nadaje. Niestety ten temat wciąż czeka na zarówno teoretyczne, jak i empiryczne opracowania.

Podsumowując rozważania zawarte $\mathrm{w}$ niniejszym artykule, warto odnieść się bezpośrednio do problematyki edukacji medialnej. Niewątpliwie mamy obecnie do czynienia $\mathrm{z}$ istotnymi brakami w tym zakresie - zarówno wśród młodszego, jak i starszego pokolenia. Wskazują na to nie tylko obserwacje otaczającej nas rzeczywistości i naszego funkcjonowania $\mathrm{w}$ świecie mediów, ale też wyniki badań związanych choćby z bezpieczeństwem dzieci i młodzieży $\mathrm{w}$ internecie, jakie cyklicznie prowadzi wiele jednostek i organizacji (na przykład NASK ${ }^{26}$ ). Być może lepsze poznanie specyfiki naszego kontaktu z nowymi mediami jest kluczem do podniesienia efektywności działań edukacyjnych i profilaktycznych w tym zakresie. A tu analiza transakcyjna daje badaczom bardzo duże możliwości. Jednocześnie, jak wynika z zaprezentowanych w niniejszym artykule treści, potencjał, jaki niesie AT, jest wciąż niewykorzystany. Inicjatyw empirycznych jest wciąż zbyt mało, aby sprostać zarówno możliwościom, jakie niesie omawiana koncepcja, jak i potrzebom generowanym przez współczesne czasy i dynamiczny rozwój nowych technologii. Należy zatem wyrazić nadzieję, iż niniejszy tekst stanie się dla wielu badaczy inspiracją i zachętą, aby sięgnąć po analizę transakcyjną i przy jej pomocy postarać się lepiej poznać specyfikę funkcjonowania człowieka w kontakcie z nowymi technologiami.

\section{Bibliografia}

Berne E., Seks i kochanie, Książka i Wiedza, Warszawa 1994.

Berne E., W co graja ludzie, Wydawnictwo Naukowe PWN, Warszawa 1994.

26 Pokolenie 3.0. w świecie wirtualnym i realnym - raport $\mathrm{z}$ badań NASK. https://www.nask.pl/download/1/447/Nastolatki30NASK.pdf [dostęp: 16.08.2018]. 
Jagieła J., Gry psychologiczne w szkole, Oficyna Wydawnicza Nauczycieli, Kielce 2004. James M., Jongeward D., Narodzić się, by wygrać, Dom wydawniczy REBIS, Poznań 2003.

Łęski Z., Duch w maszynie... Kim jest dla nas komputer? Charakterystyka relacji w języku analizy transakcyjnej, Wydawnictwo im. Stanisława Podobińskiego Akademii im. J. Długosza w Częstochowie, Częstochowa 2016.

Łęski Z., Pierzchała A., Życie w grze czy gra w życie. Rola skryptu życiowego w ksztattowaniu postaw graczy, [w:] Edukacja międzykulturowa w warunkach kultury globalnej. Od rozważań definicyjnych do praktycznych zastosowań, red. N. Dębowska, M. Walachowska, N. Starik, Wydawnictwo Wyższej Szkoły Bezpieczeństwa, Poznań 2014.

Łęski Z., Zarys problematyki komputeryzacji kształcenia w perspektywie analizy transakcyjnej, [w:] Analiza transakcyjna w edukacji, red. J. Jagieła, Wydawnictwo im. S. Podobińskiego Akademii im. J. Długosza w Częstochowie, Częstochowa 2011.

Pierzchała A., Pasywność w szkole, Diagnoza zjawiska z perspektywy analizy transakcyjnej, Wydawnictwo im. S. Podobińskiego Akademii im. J. Długosza w Częstochowie, Częstochowa 2013.

Pierzchała A., Po dwóch stronach ekranu, czyli wirtualne relacje interpersonalne w perspektywie analizy transakcyjnej, [w:] Bezpieczeństwo dzieci i młodziė̇y w przestrzeni wirtualnej - teoria i praktyka. Prace naukowe GWSP, red. E. Golbik-Madej, Gliwicka Wyższa Szkoła Przedsiębiorczości, Gliwice 2016.

Pierzchała A., Rodzic, Dorosty, Dziecko - jak można opisać komunikacje, na forach internetowych z punktu widzenia analizy transakcyjnej, [w:] Oblicza internetu. (Re)defniowanie sieci, red. M. Sokołowski, Wydawnictwo Państwowej Wyzszej Szkoły Zawodowej w Elblagu, Elbląg, 2010.

Pierzchała A., Transakcyjne zakazy $i$ nakazy skryptowe w ukrytym programie szkoty, „Edukacyjna Analiza Transakcyjna” 2017, nr 6.

Pokolenie 3.0. w świecie wirtualnym i realnym - raport z badan' NASK, https://www. nask.pl/download/1/447/Nastolatki30NASK.pdf [dostęp: 16.08.2018].

Reeves B., Nass C., Media i ludzie, Państwowy Instytut Wydawniczy, Warszawa 2000.

Stevart I., Joines V., Analiza transakcyjna dzisiaj, Dom Wydawniczy REBIS, Poznań 2017.

Wallace P., Psychologia Internetu, Dom Wydawniczy REBIS, Poznań 2005. 